\title{
A critical appraisal of the recruitment and selection process of the Public Protector in South Africa
}

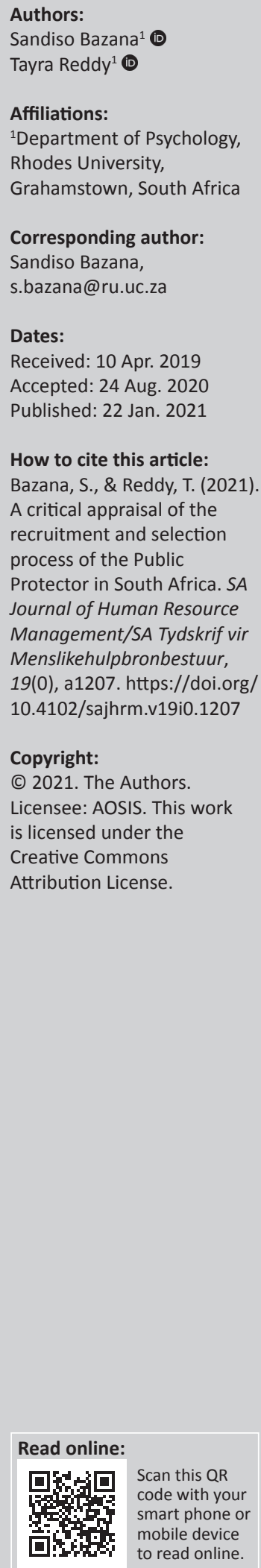

Orientation: The process of recruitment and selection the Public Protector (PP) needs to ensure that the most 'fit and proper' candidate is appointed. The process needs critical scrutiny for such a fit and proper candidate to be selected.

Research motivation: South Africa's superior courts, including the Constitutional court have recently (in 2019) labelled the current Public Protector; dishonest and Incompetent in carrying out the duties of the PP office.

Research purpose: This article critically appraises the recent process that culminated in the appointment of Ms Busisiwe Mkhwebane as the fourth Public Protector in the democratic South Africa.

Research approach: This article analysed documents, including the Constitution of the Republic of South Africa, Minutes of the meetings of the Adhoc Committee established by parliament to lead the process of the recruitment and selection of the Public Protector, and Public Protector Act.

Main findings: We found that the process of recruiting and selecting the Public Protector as it currently stands in South Africa, through the sections of the constitution, completely ignores the principles of recruitment and selection that help avoid sentiments of bias and selecting incompetent persons.

Practical implications: The findings of this paper call for a critical evaluation of the discretion that the constitution gives to only the SA parliament to initiate and undertake the process of the recruitment of the public protector.

Contribution: The contributes to the role that Human Resources Management discipline needs to play in SA, beyond its preoccupations with corporate organisations, to influence professional ethics in the Public Sector.

Keywords: Public Protector; South Africa; recruitment and selection; Ad-Hoc Committee; Constitution of South Africa; Parliamentary; Documents analysis; Competency-Based Assessment.

\section{Introduction}

South Africa (SA) became an official democratic state in 1994. This was cemented by the successful endorsement of the Constitution of South Africa in 1996 by the first democratically elected president, Mr Nelson Mandela. The Constitution of the Republic of South Africa has acted as the Holy Grail of South African law. It is the vanguard that protects the citizens from the people who are placed in power. It represents the supreme law of the land while simultaneously echoing a 'never again' message. This means that the government will no longer have the ultimate power to make unjust laws without their actions being grounded firmly in the law of the constitution (De Vos \& Freedman, 2014). The Bill of Rights that is contained in the constitution is a cornerstone of democracy in South Africa. It enshrines the rights of all people in the country and affirms the democratic values of human dignity, equality and freedom (South African History Online [SAHO], 2018). To protect the rights of people, the constitution gives rise to the separation of powers, which means that there are certain checks and balances to ensure that there is no abuse of power. The constitution has a separation of powers doctrine - aimed at limiting powers of each branch of government: the legislature, the executive and the judiciary. This means that the doctrine thus provides the basis for an institutional, procedural and structural division of public power (De Vos \& Freedman, 2014). To ensure that there is a separation of powers, as well as checks and balances on these powers, the constitution establishes Chapter 9 institutions that support the constitutional democracy. 
The Chapter 9 institutions consist of the following: the Public Protector (PP), the Auditor-General (AG), the Independent Electoral Commission (IEC), the South African Human Rights Commission (SAHRC), the Commission for Gender Equality (CGE) and lastly, the Commission for the Protection of the Rights of Cultural, Religious and Linguistic Communities. These institutions are independent and subject only to the constitution as well as the law. They must be impartial and must exercise their powers, as well as perform their functions without fear, favour or prejudice. The other organs of state, through legislative and other measures, must assist and protect these institutions to ensure the independence, impartiality, dignity and effectiveness of these institutions (Constitution, 1996). This article focusses on one of the Chapter 9 institutions: the PP.

\section{Context and problem statement}

The PP is an important Chapter 9 institution that monitors the conduct of state officials and agencies with the main aim of ensuring an effective and ethical public service (Bishop \& Woolman, 2013). The PP's brief is to watch the watchers and to ensure that the government discharges its responsibilities correctly and thus the PP can be described as the 'watchdog' (Bishop \& Woolman, 2013). This indicates the value that this institution holds in terms of protecting the public. According to Pienaar (2000), the PP is often compared to the Ombudsman. An Ombudsman is an institution that originated in Sweden and it was created to ensure that the public officials acted in terms of the law and discharged their duties properly. Pienaar (2000) argues that there are many variations in terms of structure and function, and this is dependent on the circumstances of the particular country. Pienaar (2000) further argues that Ombudsmen are established to protect and promote people's rights as well as oversee government agencies. This then acts as a link between the people and their government. Mbiada (2017) supports the argument that the PP is derived from the ombudsman. Mbiada (2017) also argues that the PP's predecessors were the Advocate General and the Office of the Ombudsman whose powers included investigating reports of maladministration, but not taking remedial action. Thus, their powers were limited to referring their findings to other institutions (Mbiada, 2017).

The origins of the PP can be found in the pre-constitutional structure that was similar to the ombudsman who was known as the Advocate General (Pienaar, 2000). According to Pienaar (2000), this was established in 1979, and it was regarded as a distinctly South African institution. The Advocate General's mandate was limited and restricted to investigating the improper use of public money (Pienaar, 2000). The office of the PP is given rise to by the constitution, and it does not fall under the three branches of government (Executive, Legislature and Judiciary); it is a separate, independent and impartial institution that is meant to be a check on governmental power and to increase government's accountability and responsibility (De Vos \& Freedman, 2014).
According to the Supreme Court of Appeal, the PP plays an important role in combating corruption. The Supreme Court of Appeal has described the institution as an 'important defence against maladministration and corruption', which 'are capable of insidiously destroying the nation' (SABC v DA, 2015). As a result, the correct person must be chosen to occupy the office of the PP. To understand why the best candidate should be selected, the human capital theory (HCT) will provide an understanding of how people can be considered as an investment towards the organisation's success. At this stage, the article will explore the developments that have taken place in this Chapter 9 institution since its inception in 1995.

\section{South African Public Protector from 1995 till date}

In 1995, President Nelson Mandela appointed Judge Selby Baqwa as the country's first PP (SAHO, 2018). According to Pillay and Ramela (2016), Baqwa did a good job in establishing the office of the PP as well as bringing awareness about the institution as well as its mandate and services. Baqwa focussed on making the PP accessible to all by establishing various offices and outreach points across the country. According to Section 183 of the constitution, the tenure of the $\mathrm{PP}$ is a non-renewable period of 7 years and thus a new PP is appointed after 7 years.

In 2002, President Thabo Mbeki's appointed Lawrence Mushwana as the new PP, who was a deputy chairperson in the National Council of Provinces (SAHO, 2018). According to Pillay and Ramela (2016), there was criticism because of Mushwana's allegiance to the African National Congress (ANC). Corruption Watch (2018) echoed this by stating that Mushwana was met with public criticism as he had previously served as deputy chairperson in the National Council of Provinces. Opposition parties felt that his known ANC alliance would taint the independence of the PP and that he would not act independently because of his political allegiance.

Mushwana aimed to expand on the programme that was implemented by Baqwa (Pillay \& Ramela, 2016). Mushwana has been credited with creating the remedial action for investigations and allowing the findings of the PP to be binding. Corruption Watch (2018) states that Mushwana was known for his 'soft findings' towards members of the ANC, and while not finding fault in certain individuals in the ANC does not constitute wrongful conduct on the part of Mushwana, Corruption Watch (2018) further argues that the somewhat soft findings and remedial action in high-profile cases brought little or no consequences for the offenders and painted the PP as a lapdog for the ruling party. Several cases show Mushwana's alleged bias towards certain ANC leaders (Corruption Watch, 2018).

In 2009, after Mushwana's 7-year term ended, President Jacob Zuma appointed Thuli Madonsela who was the former Law Reform Commissioner and human rights lawyer 
(SAHO, 2018). According to Pillay and Ramela (2016), Madonsela has been the country's most celebrated PP. Her legacy will be prominently associated with her Secure in Comfort report, which found that President Jacob Zuma unduly benefited from taxpayer-funded upgrades to his Nkandla residence that were not related to security (Pillay \& Ramela, 2016), including the State of Capture report that culminated into the Zondo State Capture Commission established by President Zuma on instructions by the PP, under Ms Madonsela.

In a 2013 survey conducted by Freedom House, Madonsela was praised widely for her work in protecting South Africa's democracy. The survey suggested she was a well-known and powerful force against corruption. In 2014, Time magazine ranked Madonsela among the top 100 most influential people in the world under the category of leaders, praising her as 'an inspirational example of what African public officers need to be' (Pillay \& Ramela, 2016). In 2016, after Madonsela's 7-year tenure ended, President Jacob Zuma appointed Busisiwe Mkhwebane as the current PP.

\section{Current Public Protector}

The selection decision of the current PP, Ms Busisiwe Mkhwebane, was questioned by SA's second main opposition party, the Democratic Alliance (DA). Important to mention that this criticism did not engage with the process of recruitment and selection that was followed by parliament, which the DA participated. What has subsequently happened, which has thus far been captured and analysed in the SA media and in SA courts, suggests for a critical analysis of the very process of recruitment and selection of the PP in SA.

A recent high court judgement regarding the Bankorp-CIEX case has resulted in calls for the removal of the current PP (Makinana, 2018). Makinana (2018) argues that there are calls for her removal on the basis that 'she misconstrued her powers and is grossly incompetent'. The Pretoria High Court, which set aside Mkhwebane's report, published in June last year, and her finding that Absa was liable to pay R1.25 billion to the government indicates that the findings of the report were not accurate and thus shows a lack of competence (Makinana, 2018). This would be followed by a spree of the court cases against her reports, as Law Expert and Professor, Pierre De Vos, recounts here. The court cases include the Constitutional Court that found the PP 'dishonest and Incompetent' (2019). Senior staffers in the office of the PP have dissociated themselves from the reports - and some have broken rank by speaking publicly about how Ms Mkhwebana runs the prestigious office of the PP as reported here (Maqhina, 2020). She refuted these allegations from within her office and labelled some of these staffers as disgruntled former employees of the office. Ms Mkwhebane though has been unable to defer the critical judgements of some of SA's superior courts that have set aside her recent reports. According to Makinana (2018), the court ordered her to pay some of her opponents' legal costs personally, stating that she did not conduct herself in a manner expected from a person occupying the Office of the PP. This has earned Ms Mkhwebane a label of 'incompetent', by critics including important different courts of South Arica.

According to Makinana (2018), the PP is facing backlash and many people are calling for her removal. Makinana (2018) further argued that the DA then chief whip John Steenhuisen wrote to the then speaker Baleka Mbete requesting that the National Assembly expedite procedures to remove Mkhwebane from office based on the court ruling. Many media pundits have interpreted many court judgements against Ms Mkwhebana as pointing out the glaring 'lack of 'knowledge on her duties and her limited powers, including 'lack of basic understanding of the constitution, her powers and duties as $\mathrm{PP}^{\prime}$ (Constitutional Court Judgement, July 2019). The current Speaker of Parliament, Ms Tandi Modise, has already expedited the process of removing the PP through parliament (Gerber, 2020).

It is at the back of all these public allegations of incompetence that this study investigates the recruitment and selection process of the PP in South Africa. With all the accolades and words of appreciation shown to the previous PP, Ms Thuli Madonsela, the first to be given the star of outstanding performance, how and what made the country select the current PP who is seemingly in public opinion and by court's judgement is lacking competence. This problem is studied within the discipline and profession of human resource (HR) management. The aim is to critically examine the process of recruiting and selecting a PP in South Africa through the framework of professional HR practices. The next section of the article will provide an overview of the process of recruitment and selection that begins with the job analysis process.

The job analysis process is an information-gathering as well as data-recording process that is used in recruitment. Depending on the type of job, different job analysis techniques can be used (Nelson, 1997). Certain steps need to be followed in a job analysis. Firstly, there is the identification of the tasks performed, then the writing of the task statement and finally the rating of the task statement. Following that is the determining of the Knowledge, Skill, Abilities, and Other Characteristics (KSAO'S) (Fine \& Getkate, 2014). There are also different types of job analysis processes that are used in different situations. The role of a job analysis is to combine the knowledge of human attributes with the task demands and from there produce a behaviour theory for the job. The two different types of job analysis that will be discussed are taskand work-oriented job analyses (Nelson, 1997). In the taskoriented approach, the actual tasks of the job are discussed and the approach looks at what will be accomplished by those specific tasks. Work-orientated approach looks at what attributes are needed to do the specific tasks (Nelson, 1997). Work approach is mainly used for training programmes as it looks at the behaviour of people more than in task analysis.

The task- and work-orientated analyses have to be conducted to ensure that the correct applicants apply for the job and 
whether the applicants meet the requirements or not. This analysis sets a benchmark of consistency that will allow for the best candidate to be chosen for the office of the PP (Nelson, 1997).

There are different types of data that need to be collected for a proper analysis. Examples of this include the work activities, work performance, the context of the job, machines, tools and so on, as well as personnel requirements. The agent of the information (known as the incumbent), as well as the incumbent's staff, is overall the most important source of information relating to the actual job analysis (Nelson, 1997).

Our initial reading of the minutes of the Ad-Hoc Committee's meetings that were set up by parliament to take charge of the process of recruitment and selection of the PP stated that information could not be gathered from the previous incumbent as they argued it would negatively affect the current process (Parliamentary Monitoring Group, 2016). The minutes of the meetings indicate that no job analysis was done for the position of the PP. The information was taken from Section 182 of the Constitution as well as from the Public Protector Act (Parliamentary Monitoring Group, 2016). This study is guided by the centrality of the human factor in making organisations (and in this case, states) succeed and achieve their intended goals, through a carefully structured recruitment and selection process, as explained by the HCT.

\section{Human capital theory}

The HCT was originally conceptualised by Adam Smith in the 18th century (Spengler, 1977). According to Lepak and Snell (1999), human capital is the knowledge and skills that an individual possesses that allow him or her to propel an organisation in the right direction. This means that for an organisation to function, the most qualified people need to be hired for the job.

The HCT argues that people are fixed capitals because they possess skills and useful abilities that yield genuine cost and profits to an organisation (Ekwoaba, Ikeije, \& Ufoma, 2015). Consequently, it highlights the importance of why the best people would need to be selected for the job. Boon, Eckardt, Lepak and Boselie (2017) argue that human capital is a resource that helps 'firms' obtain a competitive advantage.

Ekwoaba et al. (2015) argue that people and their collective skills, abilities and experience are now recognised as significant contributors to organisational success and, as a result, place great importance on recruiting and selecting the best candidates for optimum results. According to Lepak and Snell (1999), HCT is closely associated with the study of HR management, which is found in the practice of business administration. Lepak and Snell (1999) further argue that human capital is accumulated specifically for the nature of the task, and this is then vital for organisations as these tasks and skills can be transferrable in nature. Ekwoaba et al. (2015) state that consequently many organisations have placed value on HR because people offer the organisation different values, perceptions and attributes. As a result, human capital when well managed can benefit the organisation in many ways.

Ekwoaba et al. (2015) go further to argue that the HCT proposes two possible hypotheses. Firstly, the theory begins by arguing that the recruitment and selection criteria have an important effect on the performance of the organisation. This then means that if the correct candidates are recruited and selected, there is a high chance that the organisation will perform better. The second postulation is that the more objective the recruitment and selection is, the better the organisation's performance will be (Ekwoaba et al., 2015).

This article applies the theory of human capital to emphasise the importance of ensuring the credibility and fairness of the process of recruitment and selection of the PP to find suitably (fit and proper) qualified person for the job. The constitution highlights the importance of the role of the PP concerning the protection of the constitutional democracy of South Africa, and thus one could argue that using this theory concerning the PP will bring to focus the critical role of the figure of PP within the PP office.

If we take the HCT into the discourse of the PP in South Africa, we could argue that the former PP, Ms Madonsela, provided SA with 'appropriate' behaviour and competencies to be an effective PP. The HCT argues for the importance of a carefully and professionally managed recruitment and selection process for any organisation to get someone who will add value to the organisation (in this case, to the state). Thus, the HCT underpins the need for a thorough, objective recruitment and selection of the PP. This theory states the importance of people's skills and overall competencies in a given task. This then brings about the importance of recruitment and selection.

\section{Recruitment and selection}

Louw (2013) argues that competent employees make organisations effective. The process of finding and identifying competent human capital that will add the necessary value to an organisation is known as recruitment and selection and is a function of the HR management department (Grobler, Wärnich, Carrell, Elbert, \& Hatfield, 2006).

Gold defines recruitment as a process of generating a pool of capable candidates applying to an organisation for employment (Gold, 2007). The organisation attracts candidates through sources and methods. El-Kot and Leat (2008) observe that recruitment begins with advertising existing vacancies. This can be done internally and externally (Louw, 2013). For most organisations, direct applications by mail or by individuals applying in person form the largest source of applicants (Louw, 2013). The usefulness of direct applications will often depend on the image the organisation has in the business community and the eventual quality of such applicants (Beardwell, 2007). Other sources of recruitment include personal contacts, walk-ins, university 
and school campus recruiting, career fairs, recruitment agencies, newspaper advertising and direct mail postings to suitable candidates (Beardwell, 2007; Cober \& Brown, 2006; Grobler et al., 2006; Madia, 2011; Tucker, 2012; Zottoli \& Wanous, 2000).

Recently, the use of technologically advanced methods such as Twitter and cell phones (Madia, 2011; Tucker, 2012) has proved to be helpful. E-recruitment includes job postings on company homepages as well as curriculum vitae (CV) uploads to central databases. Other researchers (Pollit, 2005; Tong \& Sivanand, 2005) believe that the use of e-recruitment in the recruitment process is increasing because of its cost-effectiveness. All this leads to a process known as selection where 'applicants with experience and qualifications most closely related to job specifications may eventually be selected (Louw, 2013, p. 2).

\section{Selection}

Selection, according to Mondy (2010, p. 136), refers 'the process of choosing from a group of applicants those individuals best suited for a particular position in an organization'. The process of selection is more concerned with identifying and employing the best qualified and suitable individuals for specific positions (Louw, 2013). Louw recently referred to the importance of PersonEnvironment (P-E) fit 'when setting criteria in the selection process' (p. 3). According to Louw, P-E fit focuses (1) 'the extent to which a job provides rewards that meet the individual's needs and (2) the extent to which the applicant's skills, abilities, and experience meet the requirements of the employer (p. 3). Louw contends that 'If a misfit exists between either one of these types, an individual may develop stress during his or her stay with the employer' (p. 3).

In recent years support for a multilevel fit for selection, purposes emerged that require a variety of selection sources or techniques to appoint the desired applicant (Anderson, Lievens, Van Dam, \& Ryan, 2004; Kristof-Brown, Jansen, \& Colbert, 2002). Such approaches are the person-job fit, person-team fit and the person-organisation fit. Personteam fit has been reported in a quantitative study of 121 participants (across 30 teams) as leading to a high supplementary and complementary fit than teams with the less person-team fit (De Cooman, Vantilborgh, Bal, \& Xander Lub, 2015, abstract). A review of literature and views of HR practitioners in a study by Mercurio (2016) found a significant relationship between person and organisation fit during the selection process and recommends that: 'researchers should focus on developing valid tools such as score sheets for organizations to rate $\mathrm{P}-\mathrm{O}$ fit during the interview stage of the selection process' (p. 21).

The media reports and court cases cited above, including disagreements between PP staffers and PP - criticisms that she lacks understanding of the organisation that she occupies illustrate problems of person-environment (PP office) and person-job fit (PP job description and specification). Recruitment and selection process is not without its challenge as shown in Masibigiri and Nienaber (2011).

Harris, Brewster and Sparrow (2002) are convinced that 'the decision to use recruitment and selection methods differs from country to country and region to region. Such decisions are dictated by labour legislation and the source of recruitment that may be available from within or outside the organisation' (Louw, 2013, p. 2). In SA, legislation imperatives of affirmative action, which aims at recognising the groups that were previously disadvantaged known; designated groups, including women, disabled and blacks. The legislation encourages recruitment and selection of employees who show at least minimum requirements of the job and competencies to be selected (Ekwoaba et al., 2015).

The functions of the PP are highlighted by Section 182 of the Constitution, which state that the PP has the power as regulated by national legislation to:

- investigate any conduct in state affairs, or the public administration in any sphere of government, that is alleged or suspected to be improper or to result in any impropriety or prejudice, to report on the aforementioned conduct and to take appropriate remedial action.

- The PP has the additional powers and functions prescribed by national legislation. The PP may not investigate court decisions.

- The PP must be accessible to all persons and communities. Any report issued by the PP must be open to the public unless in exceptional circumstances, be determined in terms of national legislation and require that a report be kept confidential.

The study, after going through the minutes of the previous Ad-Hoc Committee that was established to undertake the process of recruiting and selecting the $\mathrm{PP}$, found no evidence of the committee/parliament embarking on a transparent job analysis to identify the key job description and specification of the PP (Parliamentary Monitoring Group, 2016). Such a scenario would have paramount importance, especially after the admirable precedence and conduct that former PP Madonsela demonstrated.

The second step would be to attract potential employees by advertising the job and attracting people to apply for the job. This is where Cascio and Aguinis (2008) state the important ways in which jobs can be advertised. The next stage is selecting the correct people for the job, and this is where job interviews are conducted and ability tests are taken if need be. This step is important as the HCT states the importance of talent and skills, and this is the stage where the committee can gauge the skills that the PP requires (Ekwoaba et al., 2015). The advert that was issued out on the parliamentary page shows that the section from the constitution was given verbatim and thus questions how the 
advert was created and where the job description and specification is (Parliamentary Monitoring Group, 2016).

When recruiting for a vacancy, a good job analysis must be conducted to ensure that the best person will be chosen for the job. To do a job analysis, a job analysis must be explained briefly (Cascio \& Aguinis, 2008). The process can be divided into three stages; the first is to define the requirements of the job and this is broken down into a job description and a job specification. This step aims to describe and define what the job entails and what qualifications are needed for a particular job (Cascio \& Aguinis, 2008).

\section{Research questions}

- What are the flaws in the current process from a professional recruitment and selection viewpoint?

- How can the process be strengthened to eliminate perceptions of bias and favouritism?

- Is there a better approach or can the current approach be improved to recruit and select a fit and proper PP?

To answer these questions, the study adopted a qualitative research methodology and emphasised the importance of analysing documents to identify the flaws and hopefully construct a process that could be underpinned by rigour, reliability and validity.

\section{Research methodology}

This research study has used qualitative research design. Creswell (1998) defines qualitative research as an inquiry process of understanding that is based on distinct methodological traditions that explore a social or human problem. This research has also used document analysis as a key qualitative research design, and this will be further explained in the procedures of data collection.

\section{Unit of analysis and sampling procedures and procedures of data collection}

This study has employed a purposive sampling method to identify documents that help one make sense of the most recent process that was followed by the parliament of SA to recruit and select a 'fit and proper' PP. Tongco (2007) states that purposive sampling is also known as judgement, subjective or selective sampling, and it is a technique that allows the researcher to use their judgement to choose members of a population to participate within the study.

This research project will use document analysis as a method of highlighting the importance of the recruitment and selection of the PP. Bowen (2009) defines documents as something that contains text (words), and images that have been recorded without a researcher's intervention. He also argues that documents are referred to as 'social facts', which are produced, shared and used in socially organised ways. Bowen (2009) states that document analysis is a form of qualitative research in which documents are interpreted in an attempt for researchers to give meaning to the topic they are assessing.
Bowen (2009) further argues that analysing documents integrates coding content into themes, which is similar to how focus groups or interview transcripts are analysed. This research will use the public records as the primary source of documents and these are the official, ongoing records that parliament has published (O'Leary, 2014). These documents include the minutes of the meeting that has been published on the South African parliamentary page, as well as the Constitution of the Republic of South Africa and the Public Protector Act as well as any other relevant legislature.

This research aims to use data that already exist in the form of minutes posted on the South African parliamentary page as well as other legislations such as the Public Protector Act and the constitution.

\section{Procedures for data analysis}

Documents can be interpreted in various ways, and as a result detailed planning processes must be followed as they promote reliable results (O'Leary, 2014). O'Leary (2014) further outlines an eight-step process that needs to take place when planning a document analysis. The important steps will be highlighted in this research. The first step is to create a list of texts that will be explored in this study; the Constitution of South Africa, the legislation such as the Public Protector Act as well as the minutes published on the South African parliamentary page will be the list of texts that will be used.

The second step that O'Leary (2014) highlights is to consider how the texts will be accessed while paying special attention to linguistic and cultural barriers. This research will access these documents electronically and analyse how the PP was recruited and selected. The third step would be to acknowledge and address the biases of the researcher as well as those exist in the documents (O'Leary, 2014). This research would need to identify the biases that exist with the documentation and highlight these biases in an attempt to ensure credibility. This would then lead to the last few steps: considering strategies for making sure that the data are credible, being familiar with the data that are being used, fixing ethical issues and having a backup in case the documents do not give you what you need (O'Leary, 2014).

Bowen (2009) insists that a researcher should consider the subjectivity of the author as well as the personal biases that are brought into the research. Bowen (2009) further argues that the purpose of the document needs to be thoroughly analysed, taking into consideration the target audience.

Bowen (2009) also states that thematic analysis can be considered as a way of recognising patterns that exist within the data. This method will be used when looking at the minutes of the meetings to check if there was a consistent pattern with regard to the types of questions and evaluations that were done on the candidates. 
The overall concept of document analysis can be seen as a process of evaluating documents to produce empirical knowledge while simultaneously developing an understanding (Bowen, 2009). This process must maintain a high level of objectivity so that the overall process can be valid and credible (Bowen, 2009).

\section{Findings and analysis}

This research paper will highlight some important pronouncements of the Constitution of South Africa regarding the process of selecting a PP. It will then critically appraise the pronouncements of the PP Act concerning the recruitment and selection process. Lastly, the article will explore the minutes of the most recent Ad-Hoc Committee that was responsible for the recruitment of the current PP, Ms Mkhwebane. This research project will use document analysis as a method of highlighting the importance of the recruitment and selection of the PP. Bowen (2009) states that document analysis is a form of qualitative research in which documents are interpreted in an attempt for researchers to give meaning to the topic they are assessing. To give meaning to this research paper, the following documents will be looked at: the Constitution of the Republic of South Africa, the Public Protector Act and the Parliamentary minutes of the Ad-Hoc Committee.

\section{The Constitution of South Africa, 1996}

As stated above, the constitution acts as the Holy Grail of South African law. Chapter 9 of the Constitution of the Republic of South Africa introduces the state institutions that support the constitutional democracy of the country. Six state institutions are established by this chapter, but for the research, the institution of the PP will be highlighted. Section 181 (2)-(3) highlights the establishment and governing principles of these state institutions, which ultimately strengthen the constitutional democracy of South Africa.

The functions of the PP are highlighted by Section 182, which states that the PP has the power, as regulated by national legislation to investigate any conduct in state affairs or the public administration in any sphere of government that is alleged or suspected to be improper or to result in any impropriety or prejudice, to report on the aforementioned conduct and to take appropriate remedial action. The PP has the additional powers and functions prescribed by national legislation. The PP may not investigate court decisions. The PP must be accessible to all persons and communities. Any report issued by the PP must be open to the public unless in exceptional circumstances, to be determined in terms of national legislation, require that a report be kept confidential.

The above paragraph details the functions that are set out by the constitution. The tenure of the PP is given in Section 183 and states that the PP is appointed for a non-renewable period of 7 years. Section 193 deals with the appointments and states that the PP must be women or men who are South African, who are fit and proper persons to hold the particular office and who comply with any other requirements prescribed by the national legislation. Section 193 (4) further explains that the president, on the recommendation of the National Assembly, must appoint the PP. This shows that the president could disregard the recommendation and thus brings into question the fairness of the appointment. The National Assembly must recommend persons who are nominated by a committee of the Assembly which is proportionally composed of the members of all parties that are represented in the Assembly. The recommended persons should be approved by the Assembly by a resolution adopted with a supporting vote of at least $60 \%$ of Assembly members. The selection process of professional management must be objective and does not contain any form of bias, and this is highlighted by Bazana (2016) when he states that the PP needs to be an apolitical, professional person. The National Assembly is dominated by the ruling party and thus the $60 \%$ can be easily attained to further their interests. This shows that the process cannot be dissociated from the ruling party's political interests as they are the majority and ultimately have the power (in the form of the president as well) to make the final decision.

The constitution outlines the grounds on which the PP may be removed from their office. This can be found in Section 194, which indicates that the PP may be removed from office only on grounds of misconduct, incapacity or incompetence, on a finding to that effect by a committee of the National Assembly and the adoption by the Assembly of a resolution calling for that person's removal from office.

Section 59 explains the extent to which the public may be involved in the process. It states that the National Assembly must facilitate the public's involvement in the legislative and other processes of the Assembly and its committees. They should conduct business in an open manner and hold its sittings and those of the committees, in public. However, reasonable measures can be taken to regulate the public's access including the accessibility of the media. The National Assembly may exclude the public and media access only if it is reasonable and justifiable in an open and democratic society.

The above sections aim to provide the reader with all the information that the constitution provides regarding the PP. According to the literature regarding the recruitment and selection, the constitution does not provide for a professional method to recruit and select. The constitution focusses on the functions and removal of the PP; it does not provide a detailed process of recruitment and selection that can be justifiably reliable and valid when critically appraised.

It is important to note that Section 193 of the constitution explains who appoints the PP, but it does not detail the process of recruitment and how candidates should be shortlisted. This point will further be elaborated on later in this study. The next document that will be looked at will be the Public Protector Act, and this will provide more information regarding the establishment and appointment. 


\section{The Public Protector Act}

Section 1 (A) of the act establishes that there shall be a PP for the Republic. The PP shall be a South African citizen who is a fit and proper person. The act and constitution reiterate this point about fit and proper, and there seems to be no definition regarding the competencies or attributes that would render a person as fit and proper. The act outlines a list of requirements that the PP should possess, and these state that the person who will hold the office should be a judge of a high court or a person who is admitted as an advocate or as an attorney and has, for the cumulative period of at least 10 years after having been admitted, practised as an advocate or an attorney. The person is qualified to be admitted as an advocate or an attorney and has, for a cumulative period of at least 10 years after having qualified, lectured in law at a university. The person has specialised knowledge of or has experienced for a cumulative period of at least 10 years in the administration of justice, public administration or public finance. The person has a cumulative period of at least 10 years as being a Member of Parliament. The last point states that a person may have any combination of the abovementioned for a cumulative period of 10 years to hold the office of a PP. The Act does not indicate why there is an emphasis on 10 years' experience and what bearing this 10 years of experience will have on a person's ability to complete what is required of them.

According to the literature regarding the formulation of the job specification, it can be argued that this information provided by the act is the job specification. The critique would be that there is no explicit process that is outlined within the act to show where this information was obtained and why these specific tasks are important. The literature discussed above mentions that the PP was modelled from the idea of the Ombudsman and thus ideas and specifications could have emanated from that. However, the act does not explicitly state where these specifications emanate from and why they are important.

This is the only information that the act provides regarding the establishment and appointment of the PP. At this point, it is important to highlight that the act, as well as the constitution, does not provide a clear process on how the PP is appointed. Although Section 193 of the constitution and Section $1 \mathrm{~A}$ of the act contain the heading 'appointment', there is no process on how the PP is appointed.

According to the literature, after conducting a thorough job analysis, the organisation would be required to attract the best candidates for the job and this stage is known as the recruitment stage (Gamage, 2014). The selection or appointment would be considered the final stage where the best candidate is chosen. Section 193(5) gives power to the National Assembly to create a committee that is proportionally representative of all parties in the Assembly. This committee then makes a recommendation, and according to Section 193(4), the president must appoint the PP. The information contained in the act seems to bypass the professional or scientific approach that is recruitment and selection and go straight to the appointment.

The next document that will be looked at is the minutes of the meetings that were published on the Parliamentary Monitoring Group. This page offers insight into the meetings and aims to provide a true account of the process that was followed from 2002, 2009 and 2016. Because of the lack of information regarding the process of recruitment and selection in both the act and the constitution, these meetings were used to gain insight, and the aim was to find out if a method was used to recruit and select the PP and whether or not the method is that of professional recruitment and selection.

\section{Minutes regarding the appointment of the Public Protector}

To appoint the PP, an Ad-Hoc Committee was established as per Section 193(5) of the constitution. The committee was set up and established by parliament. The aim was to elect and appoint a new PP. The committee consisted of the following political office-bearers:

- Seven members from the African National Congress (ANC).

- Four from the Democratic Alliance (DA).

- One from the Econimic Freedom Fighters (EFF).

- One from the African Chirstian Democratic Party (ACDP).

- One from the Inkatha Freedom Party (IFP).

- One from the National Freedom Party (NFP).

According to Bazana (2016), this committee consists of only politicians and thus all, respectively, represent their own parties' interests. Bazana (2016) eloquently states that the AdHoc Committee's composition greatly compromises the professional ethics of recruitment and selection. As the committee comprises only politicians, it unearths the critique that they do not possess the necessary qualifications to conduct professional recruitment and selection. The lack of qualifications in HR or recruitment can be seen from the first meeting that took place (Parliamentary Monitoring Group, 2016).

The first meeting took place on the 27 May 2016, and this is where the chairperson of the committee was elected. The secretary called for nominations and two members from the ANC elected Dr M Khoza who was an ANC member. Dr Khoza was then accepted as the chairperson of the committee (Parliamentary Monitoring Group). It is important to highlight that all members of the committee are politicians who represent their political party, and as Bazana (2016) stated, it hugely compromises the ethics of recruitment and selection.

According to the minutes, Mr S Swart (ACDP) said that 'it would be helpful to members if the criteria for the selection of the Public Protector could be provided to the Committee'. This indicates that the committee did not receive the information before the meeting. Mr N. Masondo (ANC) also asked: 'that the Committee be provided with a timetable for 
the process as soon as possible' (Parliamentary Monitoring Group). From the minutes, it can be seen that the committee members did not know what the processes would entail and what the criteria for selection were. This highlights the fact that the committee did not receive prior training and according to the recruitment and selection theory discussed above, people (also called assessors) must be trained so that the process can be professionally executed (Gamage, 2014).

The next meeting was on the 01 June 2016, and the committee was briefed on the role of the PP as well as the importance and functions that are outlined in the constitution. The committee was briefed on the legal interpretation of 'fit and proper'. According to the Parliamentary Monitoring Group (2016), Mr Nathi Mjenxane, Parliamentary Legal Advisor, said that the term 'fit and proper' person to occupy the post of the PP appeared in Section 193 of the constitution and Section 1 of the Public Protector Act. 'It was a very stringent requirement, but it was not defined or described in the legislation'.

Mr Mjenxane stated that legal scholars who interpreted the principle of 'fit and proper person' concluded that the principle served as a warranty to the public that the person occupying such a sensitive post would act ethically. There seems to be no guideline that further discusses the meaning of 'ethically'. He further explained that it was commonly accepted that a fit and proper person must show integrity, reliability and honesty. These characteristics affected the relationship between the office concerned and the public. It was concluded that honesty, integrity and reliability of the person had to be interrogated to ensure that they were fit and proper to fill the office. It is important to note, as Bazana asserts, that these features (honesty, integrity and reliability) can best be attained with some form of carefully constructed competency-based behavioural assessment methods, for example, assessment centres (Bazana, 2016). Such would require careful studying of the previous incumbent's functions where they had to use the three qualities of honesty, integrity and reliability.

The minutes stated that the committee would be 'called upon to objectively make a value judgment on whether a person was fit and proper to be the Public Protector'. It was important to note that the value judgement would not be a 'subjective' one, but rather an 'objective' one. It required a consideration of the person's qualifications and whether that person could perform his or her functions without fear, favour or prejudice.

It is also interesting to note that there seems to be no further discussion regarding 'fear, favour and prejudice' and this would speak to the importance of competency-based assessments that were highlighted by Bazana (2016). The final appointment of the PP rested with the president. The committee, through interviews, had the obligation to screen individuals who would be recommended for appointment, based on whether they were honest, had integrity, were reliable and were fit and proper to occupy the office of the PP.
It is interesting to note that the committee did not draw up a guideline to follow regarding how they would measure honesty, integrity and reliability. Bazana (2016) succinctly captures the essence of the critique by stating that (Bazana, 2016):

The public protector is required to be 'fit and proper'. That means that he or she must be honest, have integrity and be reliable. A proper job analysis would provide a more specific and detailed account of these key behavioural competencies. Because the current process relies on interviews, it opens the door for personal judgement and biases. Interview questions are not informed by a proper job analysis exercise. (Para 6)

This is why it would be important to look at the previous incumbent and her staff because as Bazana (2016) puts it:

Madonsela has provided a benchmark in terms of the required properties, characteristics and attributes to seek in her successor. Her courage and integrity brought prestige to the office and made it one of South Africa's most trusted public governance institutions.

The next meeting for the PP was held on the 22nd June, and this is where they updated the media regarding where they were with the process and what steps they would take to include the public in the process of recommending someone to be the next PP. The public was then urged to make nominations before the 24th June (Parliamentary Monitoring Group).

The next meeting that took place was on the 28th June, and this is where the committee looked at $59 \mathrm{CV}$ s of the candidates that were nominated. The minutes state that the candidates' CVs will be made available to the public, and it is interesting to note that they encourage the public to scrutinise the candidates' names. The candidates were not informed that their CVs would be made public and commenting on names and not qualifications suggest that there are judgements made that are not in line with recruitment and selection. According to HCT mentioned above, a person's name would not result in an objective judgement and a person's name would not dictate whether he or she would be capable of completing the tasks.

According to the Parliamentary Monitoring Group, the candidates would receive a questionnaire that they would have to complete and send to the committee. The information obtained would be used as supplementary information that would help the committee with shortlisting and interviewing. It is very important to note that the information on the questionnaire was not discussed and that there were no clear competencies that were communicated during the meeting. This means that there is no indication of how this questionnaire came about and who created it and how valid or fair it is. Gamage (2014) states that the shortlisting of a candidate needs to follow clear guidelines which need to be properly justified. There are no clear guidelines regarding the questionnaire which questions the professionality, reliability and validity of the method used to shortlist.

The next meeting was held on the 13th July, and this is where the committee shortlisted the candidates for interviews. 
The committee gave the names of the 14 shortlisted candidates' names, and the chairperson said that the comments made by the public assisted the committee in making an informed decision.

The committee indicated that the criteria for shortlisting came from the constitution and the Public Protector Act. The qualities to be considered were grouped into four categories: character, experience, knowledge and skills. Members proposed other qualities that should be considered during shortlisting such as managerial skills, understanding of the developmental state, understanding of the spheres of government and their relationship, financial management skills, leadership skills and HR skills. These proposed qualities seemed to be based on their personal understanding of the job and thus questions how reliable and valid they are. The committee did not justify these four categories, and the point that was made above regarding biases can be applied to this context. As Bazana (2016) argues that personal judgements leave the door open for biases.

The committee did not take into account 'experts' or previous incumbents of the office when deciding these categories. According to the job analysis process, the informationgathering stage is vital (Nelson, 1994). There is therefore a bias here to take the view of politicians only without any questioning, which again undermines all the 'rules' that apply in a fair process of recruitment and selection.

The minutes further indicate that the meeting was adjourned for $2 \mathrm{~h}$ to allow members who had not received all the relevant documents, including a completed questionnaire, to go through the documents appropriately. Later, it adjourned again for $30 \mathrm{~min}$ as some Members of Parliament (MPs) complained they had received an incomplete set of documents. It is highlighted again that the questionnaire information was not disclosed, and the committee did not explicitly discuss what competencies or information they were looking for within the questionnaire.

The committee did not seem to have the documents printed out and distributed to the members in time, and as a result there was a lot of confusion regarding the correct documentation being circulated. One of the members suggested that proceeding with the shortlisting without the questionnaires and without a proper consideration of the public comments made on the nominees might result in a disservice to the entire appointment process. The criterion for shortlisting was that of Section 1 of the Public Protector Act.

It was duly noted that the meeting was disorganised and that all members did not have the same information and documentation that was needed to shortlist the candidates. As for shortlisting procedure, no formal guidelines had been put in place and used in previous processes. The committee, therefore, had to come up with its own guidelines to be used for the shortlisting process. This would mean that every 7 years, the process will change to cater to the subjective 'feelings' and thoughts of the incumbent Ad-Hoc Committee at the time. Bazana states that this cannot be accepted as it opens up room for malpractice and poor judgement because of the subjective nature of the 'assessors' decisions. A prescriptive model which follows a professional process would help eliminate subjectivity and unqualified decisions.

This highlights that the committee as well as the constitution and Public Protector Act did not provide enough information regarding the actual process of the recruitment of the PP. It is thus clear that the committee had to come up with guidelines for the process. From the meetings and discussions, it is evident that the members all had different definitions of the four characteristics they were looking for.

Corruption Watch issued a letter to the committee stating that they wanted the process properly documented as it would promote transparency, and in an effort to comply with the requests the minutes as well as video and audio files were uploaded onto the Parliamentary Monitoring Group page. The minutes and recordings revealed that the interview process of each candidate was different because there were no standardised questions. The committee decided that (Bazana, 2016):

[T] he most commonly asked questions aimed at establishing the candidates' notions regarding their fitness and propriety to fill the post. They were also asked what their response would be to an allegation of financial impropriety by a Member of the national legislative arm of government. (Para 4)

This is highly problematic as there were no standardised questions, and this allowed members of the committee to ask irrelevant and personal questions that have nothing to do with the job requirements. Candidates were being judged based on their personal beliefs and not their ability to do the job. One of the committee members asked the candidate Judge Desai 'if he had initially denied the allegation of any sexual intercourse on his part, but had later stated in his defence that it had been consensual sexual intercourse'. The committee then reported that 'he had no control over his tongue and temper'. This question was highly unprofessional considering that the committee member knew the facts and outcomes of this case and it had no relevance to the job at hand (Parliamentary Monitoring Group, 2016). The interviews did not follow the times stipulated and candidates spent more than $20 \mathrm{~h}$ because the committee insisted that all interviews have to take place on the same day. Apart from the procedural flaws mentioned above regarding the interviews, Bazana (2016) also states that 'mere interview process is inadequate if the aim is to identify behavioural characteristics like integrity, honesty and reliability'.

There were 14 candidates that were interviewed and (Parliamentary Monitoring Group, 2016) (Maqhina, 2020):

$[M]$ embers considered each candidate - with some there was serious discussion on whether the candidate should remain in the running while for others there was little or no discussion but unanimous consensus that the candidate should be eliminated. (Para 8) 
This indicates that there was no standardisation and objectivity as the members made personal judgements on whom they thought was suitable for the position.

The committee met again and (Parliamentary Monitoring Group, 2016) (Maqhina, 2020):

[R]ecommended Adv Busisiwe Mkhwebane as the preferred candidate to the National Assembly when it tabled its reports on 31 August 2016. All Committee Members, apart from the DA, reached consensus agreement on the name of Adv Mkhwebane. (Para 8)

This process was highly subjective as members spoke of their personal encounters and perceptions regarding the candidate and the interview. Mkhwebane was then appointed as the new PP by President Jacob Zuma, despite the concerns of the EFF stating that her recommendation was received from the president's cabinet. This can be viewed as highly problematic because the president is given the power to make the ultimate decision which could be biased and from recent reports Mkhwebane has been accused of 'siding with state captors and failing to "protect the public" from corrupt officials' (Head, 2018).

This process lacked professionalism in their approach to questions and process, and this is reflected throughout the minutes of the meetings and members who complained that the process was 'informal and used harsh wording'. Bazana (2016) highlighted the importance of a competency-based assessment. This is because it is grounded in the job specification and description. He further argues that it eliminates biases and subjectivity. Bazana raises the point that competency-based assessments are also the basis on which interviews are conducted. The committee that could have used good interview questions would be aimed at identifying a 'fit and proper' candidate by interrogating their character.

The basis of competency-based assessment is that it directly measures skills and abilities specifically relating to, in this case, the job of a PP (Bazana, 2016). Competency-based assessment is highly valuable because it relates directly to the job, rather than assessing broader behavioural and past events that are not related to the job (Bazana, 2016). He further argues that the interviews conducted by the Ad-Hoc Committee were disrespectful and demeaning of some candidates' characters and professional statures. Some were subjected to unwarranted personal attacks. And some were subjected to inquisitions about their ideological positions with no relevance to the requirements of the job.

\section{Conclusion and recommendations}

According to the information discussed, it is evident that the recruitment and selection process is flawed as Bazana (2016) stated and as a result:

[T] hese problems could be addressed if a more competency based assessment selection method was used. A more professional approach would be appropriate since the key post should be occupied by an apolitical, professional person. He or she is not an elected political office bearer. (Maqhina, 2020, Para 8)
This research paper recommends that the process of recruitment and selection be rooted in the professional practices, and this can be achieved by conducting a competency-based assessment as Bazana (2016) suggested. Competency-based assessments aim to assess the individuals' ability to complete the job and thus negates room for bias and subjective preferences. The process could have been done differently had the committee consulted with an independent specialist who could have helped them create an assessment battery that was suitable for the position. This would have helped the process run efficiently, and there would be no confusion regarding what is happening. The committee members could have been trained or briefed regarding how the assessment battery would be used, and thus no one would question the validity of the outcome. Bazana (2016) stated that:

[T] he recruitment of the country's public protector would be done better if scientific recruitment methods were followed. Parliament would do well to involve recruitment professionals to ensure that its choice of a suitable candidate is both professional and fair. (Maqhina, 2020, Para 8)

This statement succinctly summarises and suggests how the process could have been carried out.

\section{Acknowledgements Competing interests}

The authors have no financial or personal interests in writing this article.

\section{Authors' contributions}

S.B. conceptualised the study, developed and collected the literature used in this study, and supervised the writing of the article. S.B. edited the article. T.R. is an Honours student who worked in this project and wrote of the article under S.B.'s supervision.

\section{Funding information}

This research received no specific grant from any funding agency in the public, commercial, or not-for-profit sectors.

\section{Ethical consideration}

This research project had to be cleared by the Rhodes University Ethics Committee. There were no ethical concerns because the PP and the Ad-Hoc Committee falls part of government institutions that aim to maintain transparency. The constitution, Public Protector Act and Parliamentary minutes were all made available to the public.

\section{Data availability statement}

Data sharing is not applicable to this article as no new data were created or analysed in this study. 


\section{Disclaimer}

The views and opinions expressed in this article are those of the authors and do not necessarily reflect the official policy or position of any affiliated agency of the authors.

\section{References}

Anderson, N., Lievens, F., Van Dam, K., \& Ryan, A.M. (2004). Future perspectives on employee selection: Key directions for future research and practice. Applied Psychology: An International Review, 53(4), 487-501. http://dx.doi.org/10.1111/ j.1464-0597.2004.00183.x

Bazana, S. (2016). South Africa should use a more scientific approach to appoint its public protector. The Conversations-Africa. Retrieved from https:// theconversation.com/south-africa-should-use-a-more-scientific-approach-toappoint-its-public-protector-64077

Beardwell, J., \& Claydon, T. (2007). Human resource management: A contemporary approach. (5th edn.) Harlow: FT/Prentice Hall.

Berger, P., \& Luckmann, T. (1991). The social construction of reality. London: Penguin Books.

Bishop, M., \& Woolman, S. (2014). Public protector. In S. Woolman \& M. Bishop (Eds.) Constitutional Law of South Africa (2nd edn., ch 24A). Cape Town: Juta.

Blustein, D.L., Schultheiss, D.E.P., \& Flum, H. (2004). Toward a relational perspective of the psychology of careers and working: A social constructionist analysis. Journal of Vocational Behavior, 64(3), 423-440. https://doi.org/10.1016/j.jvb.2003.12.008

Boon, C., Eckardt, R., Lepak, D.P., \& Boselie, P. (2018). Integrating strategic human capital and strategic human resource management. The International Journal of Human Resource Management, 29, 34-67. https://doi.org/10.1080/09585192.20 17.1380063

Boudreau, J.W., \& Ramstad, P.M. (2005). Talentship and the new paradigm for human resource management: From professional practices to strategic talent decision resource management: From profession
science. People and Strategy, 28(2), 17.

Bowen, G. (2009). Document analysis as a qualitative research method. Qualitative Research Journal, 9(2), 27-40. https://doi.org/10.3316/qrj0902027

Bratton, J., \& Gold, J. (2007). Human resource management (4th edn.). New York: Palgrave Macmillan.

Braun, V., \& Clarke, V. (2006). Using thematic analysis in psychology, Qualitative Research in Psychology, 3(2), 77-101. https://doi.org/10.1191/1478088706qp063oa

Burr, V. (2003). Social constructionism (2nd edn.). London: Routledge.

Cascio, W.F., \& Aguinis, H. (2008). Staffing twenty-first-century organizations. Academy of Management Annals, 2(1), 133-165. https://doi.org/10.5465/19416520802211461

Cober, R.T., \& Brown, D.J. (2006). Direct employers association recruiting trends survey. Washington, DC: Booz, Allen, \& Hamilton.

Corruption Watch. (2018). SA's public protectors - The legacies, part two Corruption watch. Retrieved from https://www.corruptionwatch.org.za/sas public-protectors-the-legacies-part-two/

Creswell, J.W. (1998). Qualitative inquiry and research design: Choosing among five traditions. Thousand Oaks, CA: Sage.

De Cooman, R., Vantilborgh, T., Bal, M., \& Lub, X. (2016). Creating Inclusive Teams Through Perceptions of Supplementary and Complementary Person-Team Fit: Examining the Relationship Between Person-Team Fit and Team Effectiveness. Group \& Organization Management, 41(3), 310-342.

De Vos, P. (2019, July 23). Now that the ConCourt has found the Public Protector both dishonest and incompetent, will Parliament axe her? Daily Maverick.

De Vos, P., \& Freedman, W. (eds). (2013). South African constitutional law in context. Cape Town: Oxford University Press.

Ekwoaba, J.O., Ikeje, U.U., \& Ufoma, N. (2015). The impact of recruitment and selection criteria on organisational performance. European Centre for Research and Development, 3(2), 22-32.

El-Kot, G., \& Leat, M. (2008). A survey of recruitment and selection practices in Egypt. Contemporary Middle Eastern Issues.

Fine, S.A., \& Getkate, M. (1995). Benchmark tasks for job analysis: A guide for functional job analysis (FJA) scales. Hillsdale, NJ: Lawrence Erlbaum Associates.

Gamage, A.S. (2014). Recruitment and selection practices in manufacturing SMEs in Japan: An analysis of the link with business performance. Ruhuna Journal of Management and Finance, 1(1), 37-52. https://doi.org/10.4038/suslj. of Manageme

Gerber, J. (2020, January 24). Public protector removal: Speaker Thandi Modise approves motion to begin proceedings. News24. Retrieved from https://www. news24.com/news24/SouthAfrica/News/public-protector-removal-speakerthandi-modise-approves-motion-to-begin-proceedings-20200124

Golafshani, N. (2003). Understanding reliability and validity in qualitative research. The Qualitative Report, 8(4), 597-606.
Grobler, P.A., Warnick, S., Carrel, M.R., Elbert, N.F., \& Hartfierd, R.D. (2006). Human Resource Management in South Africa (2nd edn.). London: Cornwall Institute of Management.

Head, T. (2018). Who is Busisiwe Mkhwebane, South Africa's Public Protector? Retrieved from https://www.thesouthafrican.com/who-is-busisiwe-mkhwebane/

Joppe, M. (2000). The research process. Retrieved from http://www.ryerson. $\mathrm{ca} / \sim \mathrm{mjoppe} / \mathrm{rp} . \mathrm{htm}$

Joseph, S.J. (1977). Adam Smith on human capital. American Economic Review: Papers and Proceedings, 67(1): 32-36.

Kristof-Brown, A.L., Jansen, K.J., \& Colbert, A.E. (2002). A policy-capturing study of the simultaneous effects of fit with jobs, groups, and organizations. Journal of Applied Psychology, 87(5), 985-993. http://doi.org/10.1037/0021-9010.87.5.985

Lepak, D.P., \& Snell, S.A. (1999). The human resource architecture: Toward a theory of human capital allocation and development. Academy of Management Review, 24(1), 31-48. https://doi.org/10.5465/amr.1999.1580439

Louw, G. (2013). Exploring recruitment and selection trends in the Eastern Cape. SA Journal of Human Resource Management/SA Tydskrifvir Menslikehulpbronbestuur, 11(1), Art. \#319, 10 pages. https://doi.org/10.4102/sajhrm.v11i1.319

Madia, S.A. (2011). Best practices for using social media as a recruitment strategy. Strategic HR Review, 10, 19-24.

Makinana, A. (2018). Renewed calls for public protector Mkhwebane to be removed from office. City Press. Retrieved from https://www.news24.com/SouthAfrica/ News/public-protector-must-fall-20180217

Maqhina, M. (2020, February 23). 'More colleagues to speak out' against Public Protector Busisiwe Mkhwebane. IOL News. Johannesburg. Retrieved from https://www.iol.co.za/news/politics/more-colleagues-to-speak-out-againstpublic-protector-busisiwe-mkhwebane-43272000

Masibigiri, V., \& Nienaber, H. (2011). Factors affecting the retention of Generation X public servants: An exploratory study. SA Journal of Human Resource Management, 9(1), Art. \#318, 11 pages. http://dx.doi.org/10.4102/sajhrm.v9i1.318

Mbiada, C. (2017). The public protector as a mechanism of political accountability The extent of its contribution to the realization of the right to access adequate housing in South Africa. Potchefstroom Electronic Law Journal, 20, 1-34. https:// doi.org/10.17159/1727-3781/2017/v20i0a1382

Mercurio, Z.A. (2015). Affective Commitment as a Core Essence of Organizational Commitment: An Integrative Literature Review. Human Resource Development Review, 14(4), 389-414.

Mondy, R.W. (2010). Human resource management (11th edn.). Prentice-Hall: Upper Saddle River, NJ: Prentice Hall.

Nelson, J.B. (1997). The boundaryless organization: Implications for job analysis, recruitment, and selection. People and Strategy, 20(4), 39.

O'Leary, Z. (2014). The essential guide to doing your research project (2nd edn.). Thousand Oaks, CA: Sage.

Parliamentary Monitoring Group. (2016). Interviews for Public Protector position PMG. Retrieved from https://pmg.org.za/committee-meeting/23063/

Pienaar, G. (2000). The role of the public protector in fighting corruption. African Security Studies, 9(2), 52-66. https://doi.org/10.1080/10246029.2000.9627920Pi Ilay, K., \& Ramela, N. (2016). The highlights and lowlights of being Public Protector. city Press. Retrieved from https://city-press.news24.com/News/the-highlightsand-lowlights-of-being-public-protector-20160414

Pollit, P. (2005). Testing graduates at Lloyds TSB: How banks select the people who will lead it into the future? Human Resource Management International Digest, 13(1), 12-14. http://doi.org/10.1108/09670730510576347

Republic of South Africa (RSA). (1996). Constitution of the Republic of South Africa. Pretoria: Government Printers.

South African History Online. (2019). The history of the Bill of Rights. Retrieved from https://www.saha.org.za/billofrights/the_birth_of_the_bill_of_rights.htm

South African Legal Information Centre. (2019). Public protector $v$ South African Reserve Bank (CCT107/18) [2019] ZACC 29; 2019 (9) BCLR 1113 (CC); 2019 (6) SA 253 (CC), Retrieved 22 July 2019, from http://www.saflii.org/za/cases/ ZACC/2019/29.html

Southern African Legal Information centre. (2015). South African Broadcasting Corporation Soc Ltd and Others v Democratic Alliance and Others (393/2015)
[2015] ZASCA 156; [2015] 4 All SA 719 (SCA); 2016 (2) SA 522 (SCA) Retrieved [2015] ZASCA 156; [2015] 4 All SA 719 (SCA); 2016 (2) SA 522 (SCA) Retrieved
8 October 2015, from http://www.saflii.org/za/cases/ZASCA/2015/156.html

Tong, D., \& Sivanand, C. (2005). E-recruitment service providers review: International and Malaysian. Employee relations, 27(1), 103-117.http://doi.org/10.1108/0142 5450510569337

Tongco, M.D.C. (2007). Purposive sampling as a tool for informant selection Ethnobotany Research and Applications, 5, 147-158. https://doi.org/10.17348/ era.5.0.147-158

Willig, C. (2013). Introducing qualitative research in Psychology (3rd edn.). Oxford: Oxford University Press.

Zottoli, M.A., \& Wanous, J.P. (2000). Recruitment source research: Current status and future directions. Human Resource Management Review, 10(4), 353-382. 